\title{
Kemampuan Motorik Halus Anak melalui Kegiatan Melipat Kertas Origami
}

\author{
(Improving Children Fine Motor Ability through Origami Folding Activity)
}

\author{
Febriyani Harahap ${ }^{1}$, Seprina ${ }^{2}$ \\ ${ }^{1}$ Pendidikan Islam Anak Usia Dini, STAI Syekh H. Abdul Halim Hasan Al-Islahiyah Binjai \\ ${ }^{2}$ TK Raisyah Padangsidimpuan \\ ${ }^{1}$ febriyaniharahap@gmail.com, 2seprinalubis@gmail.com
}

\begin{tabular}{ccc}
\hline First received: & Revised: & Final Accepted: \\
16 November 2019 & 20 November 2019 & 20 December 2019 \\
\hline
\end{tabular}

\begin{abstract}
The phenomenon needing to consider at this time is the lack of development of fine motor children in the daily activity. Simple things such as buttoning their clothes, combing their hair, wearing shoelaces, folding their clothes, in fact, are difficult to do for children in Taman Kanak-Kanak Raisyah Padangsidimpuan. Therefore, this study aimed to improve children's fine motor skills through folding paper origami. This type of research used classroom action research consisting of 2 cycles. The research was carried out in Taman Kanak-Kanak Raisyah Padangsidimpuan in group B with 15 children consisted of 9 boys and 6 girls. Based on the results found through observation techniques, interviews, tests, and documentation, it was concluded that folding paper origami can improve the fine motor skills of children in group B of Taman Kanak-Kanak Raisyah Padangsidimpuan. It could be seen from the achievement value in the first cycle stage only $33 \%$. Whereas after the second cycle was done, the achievement of the value obtained reached $86 \%$.
\end{abstract}

Keywords: Fine Motor, Folding Paper, Origami

\begin{abstract}
Abstrak
Fenomena yang perlu diperhatikan saat ini yaitu kurang berkembangnya motorik halus anak dalam melakukan aktivitas sehari-hari. Hal sederhana seperti mengancingkan baju sendiri, menyisir rambut, memakai tali sepatu, hingga melipat baju sendiri, faktanya sulit dilakukan anak di TK Raisyah Padangsidimpuan. maka dari itu, penelitian ini dilakukan bertujuan untuk meningkatkan kemampuan motorik halus anak melalui kegiatan melipat kertas origami. Jenis penelitian menggunakan penelitian tindakan kelas yang terdiri dari 2 siklus. Penelitian ini dilaksanakan di Taman Kanak-Kanak Raisyah Padangsidimpuan dengan Subjek Penelitian yaitu anak TK kelompok B yang berjumlah 15 orang yang terdiri dari 9 laki-laki dan 6 perempuan. Berdasarkan hasil yang ditemukan melalui teknik observasi, wawancara, test, dan dokumentasi, maka disimpulkan bahwa kegiatan melipat kertas origami dapat meningkatkan kemampuan motorik halus anak di kelompok B Taman Kanak-Kanak Raisyah. Hal ini dapat dilihat dari capaian nilai pada tahap siklus I hanya $33 \%$. Sedangkan setelah dilakukan siklus II capaian nilai yang diperoleh yaitu mencapai $86 \%$.
\end{abstract}

Kata Kunci: Motorik Halus, Melipat Kertas, Origami 


\section{PENDAHULUAN}

Kreativitas menrupakan hal yang sangat erat kaitannya dengan dunia pendidikan anak usia dini. Kreativitas guru dalam menciptakan sebuah kegiatan belajar berpengaruh terhadap pengoptimalan aspek perkembangan anak. Salah satu aspek yang penting untuk dikembangkan yakni aspek kemampuan motorik. Motoric memungkinkan anak untuk melibatkan seluruh panca indera dan anggota tubuhnya untuk bermain. Hal ini sangat penting untuk tumbuh kembang anak usia dini.

Menurut Bambang (2019) kemampuan motorik anak terbagi menjadi dua bagian yaitu gerak motorik kasar dan gerak motorik halus. Gerak motorik kasar adalah kemampuan yang membutuhkan koordinasi sebagian besar bagian tubuh anak oleh karena itu, biasanya memerlukan tenaga karena dilakukan oleh otot-otot besar, sedangkan, gerak motorik halus adalah gerak yang melibatkan bagian-bagian tubuh tertentu saja dan dilakukan oleh otot-otot kecil, seperti keterampilan menggunakan jari-jari tangan dan gerak pergelangan tangan yang tepat yang sering membutuhkan kecermatan dan koordinasi mata dengan tangan.

Berdasarkan observasi yang dilakukan peneliti di kelas B TK Raisyah Padangsidimpuan, peneliti menemukan berbagai fenomena yaitu kurang berkembangnya motorik halus anak ini bisa terlihat dari kegiatan sehari-hari anak. Anak kesulitan mengancingkan baju sendiri, menyisir rambut, memakai tali sepatu, hingga melipat baju sendiri. Maka disini peneliti mencoba memecahkan permasalahan tentang motorik halus anak dengan kegiatan melipat kertas origami, sehingga peneliti dapat memperbaiki motorik halus anak untuk kedepannya.

Istilah kemampuan memiliki banyak arti, menurut Rusyan, dkk. (1992) Kemampuan artinya perilaku yang rasional untuk mencapai tujuan yang diisyaratkan sesuai dengan kondisi yang diharapkan. Poerwadarminto (1994) menjelaskan bahwa kemampuan adalah kesanggupan, kecakapan, kekuatan dalam melakukan sesuatu tindakan atau kegiatan.

Motorik merupakan pengendalian gerak tubuh melalui kegiatan yang telah terkoordinasi antara susunan syaraf, otot dan otak. Menurut Sujiono (2008), Motorik Halus adalah gerakan tubuh yang hanya melibatkan otot-otot kecil seperti keterampilan menggunakan jari jemari tangan, dan gerakan pergelangan tangan yang tepat. Semakin baik gerakan motorik halus membuat anak dapat berkreasi, seperti menggunting, menggambar, mewarnai, menulis, meronce, merobek, melipat, meremas, menggenggam dan sebagainya dengan baik.

Sedangkan menurut Sumantri (2005) menyatakan bahwa keterampilan motorik halus adalah pengorganisasian penggunaan sekelompok otot-otot kecil seperti jari jemari dan tangan yang sering membutuhkan kecermatan dan koordinasi mata dengan tangan. Hal yang sama dikemukakan oleh Mahendra (Sumantri 2005) keterampilan motorik halus (fine motor skill) merupakan keterampilan yang memerlukan kemampuan untuk mengontrol otot-otot kecil/halus untuk mencapai pelaksanaan keterampilan yang berhasil.

Dari beberapa pendapat diatas dapat disimpulkan bahwa kemampuan motorik halus adalah kesanggupan dalam suatu bidang tertentu yang berhubungan dengan gerakan yang melibatkan bagian-bagian 
tubuh tertentu saja dan dilakukan oleh otot-otot kecil/halus seperti keterampilan menggunakan jari jemari tangan, dan gerakan pergelangan tangan yang tepat, sehingga keterampilan motorik halus anak perlu diasah sedemikian rupa.

Menurut Suyanto (2005) motorik halus berfungsi untuk gerakan-gerakan bagian tubuh yang lebih spesifik seperti menulis, melipat, merangkai, mengancing baju, menali sepatu dan menggunting. Sedangkan menurut Saputra dan Rudyanto (2005) fungsi pengembangan motorik halus adalah sebagai alat untuk mengembangkan koordinasi kecepatan tangan dengan gerakan mata, dan sebagai alat untuk melatih penguasaan emosi.

Sumantri (2005) menyebutkan bahwa tujuan motorik halus anak untuk anak usia 5-6 tahun yaitu:

a. Mampu mengembangkan kemampuan motorik halus yang berhubungan dengan keterampilan kedua tangan

b. Mampu mengendalikam emosi dalam beraktivitas motorik halus

c. Mampu menggerakkan anggota tubuh yang berhubungan dengan gerak jari jemari tangan seperti kesiapan menulis, menggambar dan memanipulasi benda

d. Mampu mengkoordinasikan indra mata dan aktivitas tangan dapat dikembangkan melalui kegiatan permainan membentuk atau memanipulasi dari tanah liat/lilin/adonan, mewarnai, menempel, menggunting, melipat, merangkai benda dengan benang (meronce)

e. Secara khusus tujuan keterampilan motorik halus untuk anak (4-6) tahun adalah anak dapat menunjukkan kemampuan menggerakkan anggota tubuhnya terutama terjadinya koordinasi mata dengan tangan sebagai persiapan untuk menulis.

Melipat/Origami berasal dari bahasa Jepang yakni "oru" berarti melipat dan "kami" atau "gami" berarti kertas. Menurut Hajar Parmadhi dan Evan Sukardi S (2008), melipat/origami adalah seni melipat kertas untuk membentuk karya tiga dimensi, dan meremas kertas lalu membentuknya kembali, merupkan karya rupa tiga dimensi yang ekspresif. Tehnik ini mirip dengan papier mage yaitu bubur kertas yang dibentuk.

Dasar-dasar melipat menurut (Sumanto, 2005) adalah sebagai berikut:

a. Gunakan jenis kertas yang secara khusus dipersiapkan untuk melipat.

b. Setiap model lipatan, ada yang dibuat dari kertas berbentuk bujur sangkar, bujur sangkar ganda, empat persegi panjang, dan segi tiga. Misalnya untuk lipatan model rumah, perahu, bunga, kapal terbang, dan lain-lain.

c. Untuk memudahkan melipat berdasarkan gambar kerja (pola), kenalilah petunjuk dan langkah langkah pembuatannya.

Menurut Sumanto (2005) langkah kerja melipat sebagai berikut:

a. Tahap persiapan, dimulai dengan menentukan bentuk, ukuran, dan warna kertas yang digunakan untuk kegiatan melipat. Juga dipersiapkan bahan pembantu dan alat yang diperlukan sesuai model yang akan dibuat.

b. Tahap pelaksanaan, yaitu membuat lipatan tahap demi tahap sesuai gambar pola (gambar kerja) dengan rapi menurut batas setiap tahapan lipatan sampai selesai.

c. Tahap penyelesaian, yaitu melengkapi bagian-bagian tertentu pada hasil lipatan. 
Melipat lurus dan melipat miring perlu diberikan sebagai dasar dalam melatih kemampuan anak pada kegiatan melipat kertas ke berbagai arah atau posisi dengan menggunakan beberapa ukuran kertas. Melipat lurus dan melipat miring merupakan cara/pendekatan yang harus dilakukan dalam pembuatan suatu model lipatan

\section{METODE}

Metode penelitian menggunakan penelitian tindakan kelas yang terdiri dari 2 siklus. Penelitian ini dilaksanakan di Taman Kanak-Kanak Raisyah Padangsidimpuan dengan Subjek Penelitian yaitu anak TK kelompok B yang berjumlah 15 orang yang terdiri dari 9 lakilaki dan 6 perempuan. Dalam pengumpulan data pada penelitian ini menggunakan tehnik observasi, wawancara, dokumentasi dan tes.
Dalam menginterpretasikan hasil analisis yang dilakukan pada saat proses kegiatan melipat kertas origami berlangsung, peneliti menggunakan analisi presentase untuk memperoleh gambaran tentang upaya meningkatkan kemampuan motorik halus anak melalui kegiatan melipat kertas origami, dan tes analisis dengan menggunakan nilai rata-rata anak dan kriteria ketuntasan belajar anak. Penelitian ini dianggap berhasil apabila hasil yang dicapai anak telah mencapai $80 \%$ dalam melakukan kegiatan motorik halus melalui kegiatan melipat kertas origami.

\section{HASIL TEMUAN DAN PEMBAHASAN}

Hasil dari penelitian yang diperoleh guru dan supervisor melalui observasi selama proses kegiatan meliputi rencana, pelaksanaan, pengamatan dan refleksi pada tindakan perbaikan siklus I adalah sebagai berikut:

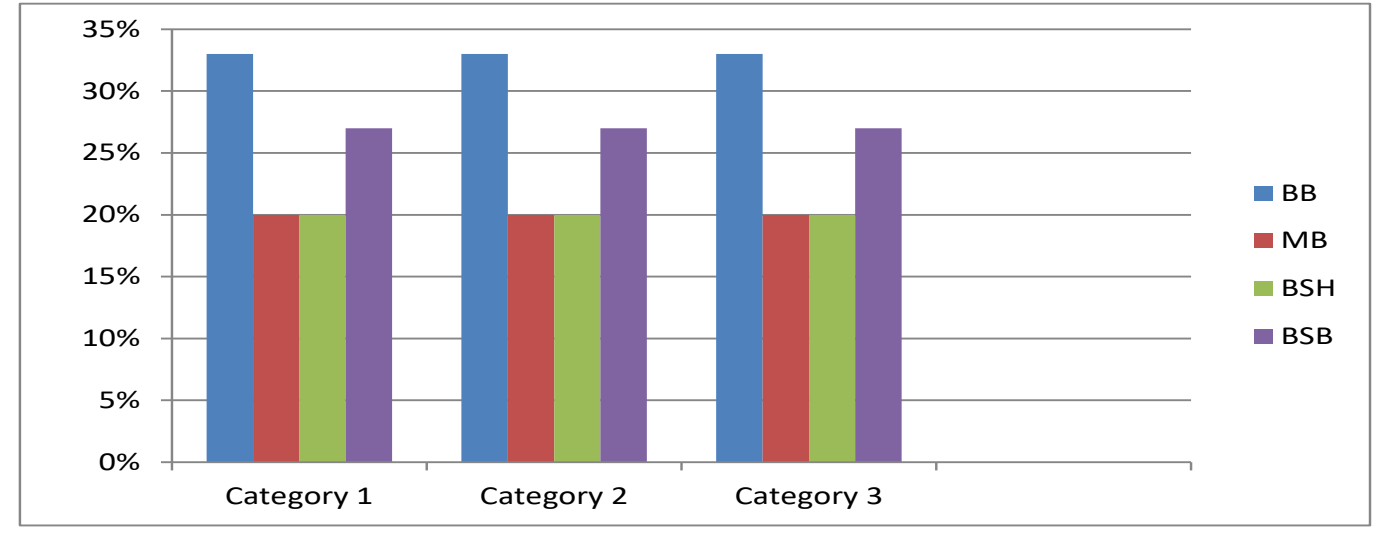

Gambar 1. Diagram Batang Hasil Penilaian Siklus I

Keterangan

BB : Belum Berkembang

MB : Mulai Berkembang

BSH : Berkembang Sesuai Harapan

BSB : Berkembang Sangat Baik

Dari hasil yang dilakukan oleh 15 orang anak yang BSB 4 orangdengan peresentase $27 \%, \mathrm{BSH} 3$ orang dengan persentase $20 \%$, dan $\mathrm{MB} 3$ orang dengan persentase $20 \%$, dan BB 5 orang dengan persentase $33 \%$. Dengan demikian tingkat keberhasilan pelaksanaan kegiatan melipat dengan kertas origami hanya (BSH dan BSB) $33 \%$. Hal itu menunjukkan tingkat keberhasilan dalam melakukan kegiatan melipat dengan kertas origami untuk meningkatkan kemampuan motorik halus 
anak masih tergolong rendah atau belum mencapai tingkat pengembangan yang diharapkan.

Berdasarkan hasil refleksi pada kegiatan siklus I, untuk itu dalam pelaksanaan pembelajaran pada kegiatan siklus II dilakukan perbaikan pembelajaran dengan hasil dan temuan sebagai berikut:

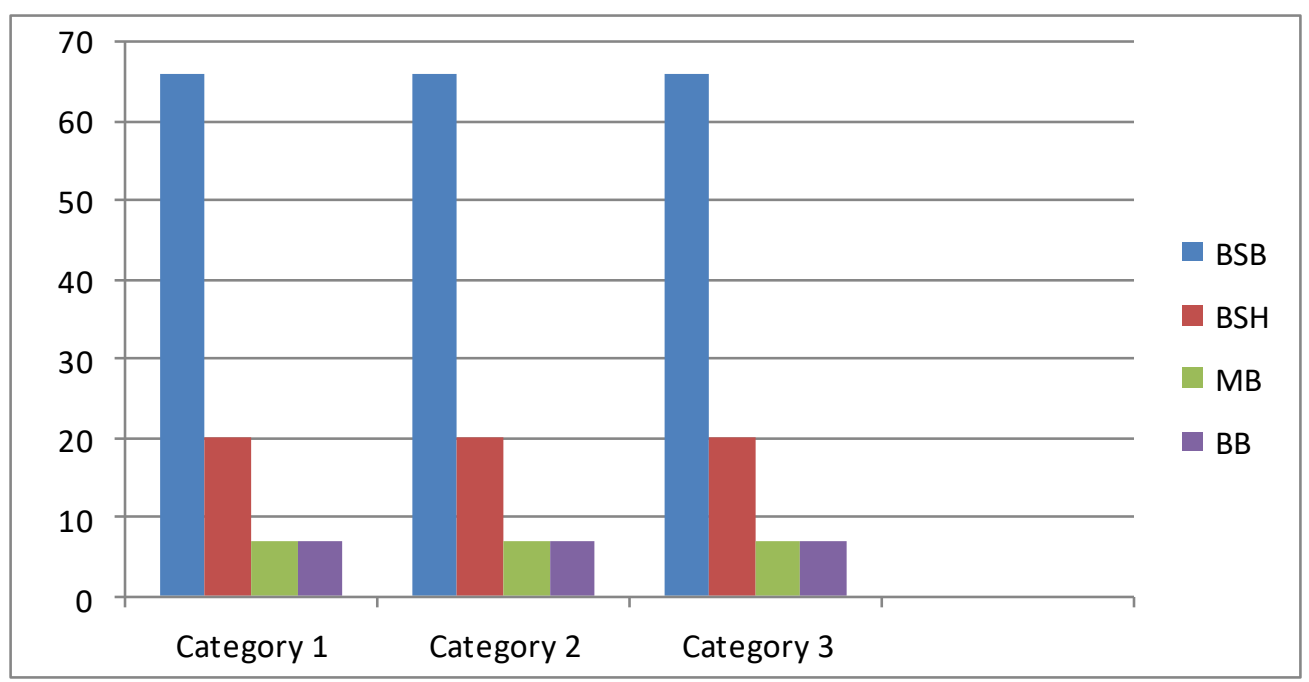

Gambar 2. Diagram Batang Hasil Penilaian Siklus II

$\begin{array}{ll}\text { Keterangan } & \\ \text { BSB } & \text { : Berkembang Sangat Baik } \\ \text { BSH } & \text { : Berkembang Sesuai Harapan } \\ \text { BB } & \text { : Belum Berkembang } \\ \text { MB } & \text { : Mulai Berkembang }\end{array}$

Dari data penilaian grafik diatas terlihat bahwa kegiatan melipat yang dilaksanakanpada siklus II menunjukkan perkembangan yang sangat baik dan telah mencapai tingkat perkembangan sesuai harapan yaitu $86 \%$. Dengan demikian, melalui kegiatan melipat dengan kertas origami dapat meningkatkan kemampuan motorik halus anak di TK Raisyah Padangsidimpuan tahun pelajaran 2018/2019. Dengan demikian dapat dinyatakan bahwa kegiatan melipat dengan kertas origami berhasil dengan baik sehingga perbaikan kegiatan berhenti sampai pada siklus II dan tidak perlu lagi melaksanakan perbaikan siklus III.

\section{SIMPULAN}

Dari hasil penelitian dapat disimpulkan bahwa kegiatan melipat kertas origami dapat meningkatkan kemampuan motorik halus anak di kelompok B TK Raisyah. Hal ini dapat dilihat dari capaian nilai pada tahap siklus I hanya 33\%. Sedangkan setelah dilakukan siklus II capaian nilai yang diperoleh yaitu mencapai $86 \%$.

Faktor penyebab keberhasilan dari penelitian ini adalah, penjelasan kegiatan pembelajaran sebaiknya mudah dimengerti anak, pengorganisasian kelas lebih dikondisikan agar dapat melakukan kegiatan lebih baik, danmedia yang digunakan menarik perhatian anak dan memotivasi anak. 
DAFTAR PUSTAKA

Sumantri, M. S. (2005). Pengembangan Keterampilan Motorik Anak Usia Dini. Jakarta: Dinas Pendidikan.

Pamadhi, H. \& Sukardi, E. (2008). Seni Keterampilan Anak. Jakarta: Universitas Terbuka.

Poerwadarminta, W. J. S. (1990). Kamus Besar Bahasa Indonesia. Jakarta: Balai Pustaka.

Rusyan, T., Kusdinar, A. \& Arifin, Z. (1992). Pendekatan Dalam Proses Belajar Mengajar. Bandung: PT Remaja Rosdakarya.
Sujiono, B., et. al. (2009). Metode Pengembangan Fisik. Jakarta: Universitas Terbuka.

Sumanto. (2005). Pengembangan Kreativitas Seni rupa Anak TK. Jakarta: Depdiknas.

Suyanto, S. (2005). Konsep Dasar Anak Usia Dini. Jakarta: Departemen Pendidikan Nasional.

Saputra, Y. M. \& Rudyanto, (2005). Pembelajaran Kooperatif untuk Meningkatkan Keterampilan Anak TK. Jakarta: Departemen Pendidikan Nasional. 